\title{
Exploring the impact of firm- and relationship-specific factors on alliance performance: Evidence from Turkey
}

\author{
A. Esen ${ }^{a^{*}}$ and G. Alpay

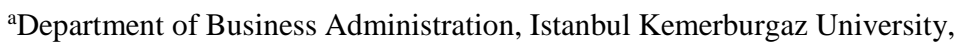 \\ Mahmutbey Dilmenler Cad. No:26 Bagcilar, Istanbul, Turkey \\ ${ }^{b}$ Department of Management, Bogazici University, Bebek, Istanbul, Turkey \\ *To whom all correspondence should be addressed \\ ayla.esen@kemerburgaz.edu.tr
}

\begin{abstract}
This study investigates the impact of firm-specific (i.e., alliance orientation and partner selection criteria) and relationshipspecific (i.e., strategic fit, cultural fit, and organizational fit) factors on alliance performance and assesses the mediating role of trust in the relationship between relationship-specific factors and alliance performance. Partial least squares analysis is applied to a data set of 106 strategic alliances, including both equity alliances (joint ventures) and non-equity alliances (contractual alliances). The empirical results reveal that alliance orientation and strategic fit lead to superior alliance performance and that cultural fit is positively related to partner trustworthiness. The results have managerial implications regarding how to maximize the positive outcomes of an alliance.
\end{abstract}

\section{Introduction}

Strategic alliances have emerged as a popular strategy, and they are increasingly being utilized in various forms by organizations. As firms recognize the benefits of collaboration, strategic alliances have become wellestablished organizational forms and means of strategy implementation in businesses (Beamish \& Delios, 1997; Chand \& Katou, 2011; Yoshino \& Rangan, 1995). The increasing prominence of strategic alliances has thus attracted the attention of many researchers. In general terms, strategic alliances are considered a type of cooperative business arrangement between business organizations. To constitute a strategic alliance, an inter-firm arrangement must lead to cooperation between firms and must help all parties in the collaboration (partners) achieve their strategic objectives (Das \& Teng, 1998a; Digman, 1999; Lynch, 1993).

Much work has focused on strategic alliances in the past three decades, giving rise to several theoretical frameworks and empirical studies, such as transaction cost theory (Kogut, 1988; Williamson, 1985), the industrial organization model (Hagedoorn, 1993), game theory (Parkhe, 1993), knowledge building and organizational learning (Kogut \& Zander, 1992; Nonaka, 1991), the network perspective (Auster, 1990) and the resource-based view of the firm (Barney, 1991; Das \& Teng, 1998b; Eisenhardt \& Schoonhoven, 1996; Lin, Young \& Arya, 2009). Previous research on strategic alliances has focused on partner selection issues, particularly on the role of specific traits or characteristics that may be important in partner selection (e.g., partner's reputation, trust) (Das \& Teng, 1998a; Hitt, Dacin, Levitas, Arregle \& Borza, 2000). Later, the relational characteristics of strategic alliances, such as complementarity and partner fit have gained importance among researchers (Rice, Liao, Martin \& Galvin, 2012; Shah \& Swaminathan, 2008; Swoboda, Meierer, Foscht \& Morschett, 2011). Given that firms seek to achieve superior performance by developing both firm-specific and relationship-specific capabilities, examining how these capabilities affect alliance outcomes and how the dynamics of these capabilities change as the relationship between partners matures would be interesting. Accordingly, this study addressed this research gap by analyzing the impact of firm- and relationship-specific factors on strategic alliance performance. The main argument of the hypothesized model is that firm- and relationship-specific alliance capabilities are critical for ensuring superior alliance performance. Additionally, trust is theorized to mediate the relationship between relationship-specific characteristics and alliance performance. The hypothesized relationships are empirically tested by using a sample of equity and non-equity strategic alliances in Turkey.

\section{Literature review and hypothesis development}

\section{Firm-specific factors: Alliance capabilities}

A number of theoretical perspectives offer insights into the issue of how firms might develop organizational capabilities. These perspectives primarily include the resource-based view (Das \& Teng, 1998b; Eisenhardt \& Schoonhoven, 1996), dynamic capabilities (Teece, Pisano \& Shuen, 1997), and organizational learning and the knowledge-based view of the firm (Kogut \& Zander, 1992). According to these perspectives, firms that are able to build distinct capabilities will outperform their rivals. In fast-changing domestic and global markets, strategic alliances have become essential for building and maintaining competitive strength. Organizations 
that develop alliance-oriented systems and procedures, that are able to learn from their alliance experiences, and that are able to select appropriate partners are considered to have strong alliance capabilities (Carlson, Madhok, Varman \& John, 2011; Kandemir, Ghauri \& Cavusgil, 2002). These capabilities, namely, alliance orientation and partner selection criteria, are referred to as "firm-specific factors of strategic alliances" in this study.

\section{Alliance orientation}

Alliance-oriented organizations learn about strategies, objectives, and the needs of their alliances. They improve their knowledge by learning from new alliance members and by searching for alliance information, and they then share and diffuse this information within their organizational systems (Argyris \& Schön, 1978). Kandemir et al. (2002) define alliance orientation as "the extent to which an organization acquires information from its alliances, analyzes the alliance information, disseminates it internally, and takes action to meet the needs of alliances to achieve satisfactory collaboration" (p.804). A number of studies highlight the importance of developing alliance-driven capabilities as an advantageous resource for outperforming competitors (Carlson, Franwick \& Cuminskey, 2011; Kandemir, Yaprak \& Cavusgil, 2006). The alliance orientation construct was developed by Kandemir et al. (2006) by following a structure that is parallel to the conceptualization of the market orientation construct in the marketing literature (Narver \& Slater, 1990). Specifically, Kandemir et al. (2006) define three dimensions that form the construct of alliance orientation: (1) alliance scanning, (2) alliance coordination, and (3) alliance learning: Alliance scanning is closely related to the proactiveness of a firm in terms of alliance formation. Alliance coordination enhances firms' ability to share knowhow and experiences with their partners and to develop and maintain synergy (Anderson \& Narus, 1990). Alliance learning is gained through the accumulation of alliance management know-how from a firm's prior and ongoing alliance experiences. Because a firm's alliance orientation is an important component of alliance management, a firm that has developed alliance scanning, alliance coordination, and alliance learning capabilities will achieve higher alliance performance than a firm that has not (Jiang \& Li, 2008; Kale $\&$ Singh, 2007). Therefore, we propose the following hypothesis:

Hypothesis 1. Higher levels of alliance orientation will be associated with higher levels of alliance performance.

\section{Partner selection criteria}

Partner selection is a critical issue in strategic alliance formation. The process of alliance partner selection must be considered a critical firm-specific capability, as successful strategic alliances are associated with the selection of appropriate partners (Chand \& Katou, 2011; Sarkar, Echambadi, Cavusgil \& Aulakh, 2001). In the strategic alliance literature, the criteria for judging the appropriateness of an alliance partner usually converge in a list comprising complementarities such as the strategic, cultural, and organizational fit between the partners, the partners' past successful experiences, and the partners' legitimacy (Child, Faulkner \& Tallman, 2005; Kanter, 1994; Li \& Rowley, 2002; Porter \& Fuller, 1986; Pansiri, 2008). While examining partner complementarities, however, Kanter (1994) takes a different approach to the partner selection process. She asserts that three fundamental factors should be used to evaluate partners: self-analysis (whether partners know themselves), chemistry (whether executives of partner firms get along well), and compatibility (whether cultures, philosophies, and ways of doing business are compatible).

A firm's adopted partner selection process is another critical alliance capability. The selection of appropriate alliance partners is generally argued to lead to effective interorganizational alliances (Chand \& Katou, 2011; Child et al., 2005; Kanter, 1994; Porter \& Fuller, 1986; Sarkar et al., 2001). Therefore, in this study, we argue that the application of a greater number of criteria in alliance partner selection will lead to high alliance performance. We thus propose the following hypothesis:

Hypothesis 2. The application of higher levels of criteria in partner selection will be associated with higher levels of alliance performance.

Relationship-specific factors: Strategic fit, cultural fit, and organizational fit

Strategic alliances are cooperative agreements between firms; therefore, the relationship between partners is a critical issue for the evaluation of strategic alliance dynamics. In the interorganizational context, various forms of fit between partners are related to alliance outcomes such as alliance performance and alliance success (Aiuniddin, Beamish, Hulland \& Rouse, 2007; Lin, Yang \& Arya, 2009; Swoboda et al., 2011). The decision to form an alliance with a specific partner usually results from the existence of complementary assets and needs, as well as mutually beneficial goals (Wohlsetter, Smith \& Malloy, 2005). The quality of relationship-specific factors (i.e., strategic fit, cultural fit, and organizational fit) is critical to the success of alliance formation and management.

\section{Strategic fit}

Strategic fit is one of the basic qualities sought in an alliance partner. Strategic fit can be defined as the extent to which alliance partners have congruent firm-level strategies, as well as compatible strategies for the alliance itself, and the strengths and capabilities of the partners form a synergy within the alliance (Taylor, 2005). Porter and Fuller (1986) argue that both complementary assets and potential synergies are necessary for success but that each is insufficient by itself. The existence of synergies between the partners increases their potential for achieving a competitive advantage. As another important condition for continued success in an alliance, the long-term objectives and strategic orientations of the partners must not conflict (Speakman \& Sawhney, 1991; Swoboda et al., 2011). Good strategic fit is likely to arise for 
partners of similar strength, with a similar degree of need for mutual resources or skills, and with congruent or at least not conflicting objectives (Child et al., 2005; Lunnan \& Haughland, 2008). As strategic fit contributes to the probability of alliance success (Hoffman \& Schlosser, 2001; Swoboda et al., 2011), we propose the following hypothesis:

Hypothesis 3. Higher levels of strategic fit between partners will be associated with higher levels of alliance performance.

\section{Cultural fit}

Cultural fit refers to the harmony of organizational philosophies, goals, and values between alliance partners (Sarkar et al., 2001; Swoboda et al., 2011). Similarity in organizational values facilitates behavioral control (Das \& Teng, 1998a; Meirovich, 2010), while social incompatibility may negatively influence collaborative effectiveness (Sarkar, Cavusgil \& Evirgen, 1997). A consistent finding in the strategic alliance literature is that incompatible cultures cause many alliance failures. According to Child et al. (2005), a good strategic fit without a cultural fit leads to a "technological trap", in which firms stick together despite achieving suboptimal results driven by a bad relationship. Therefore, we propose the following hypothesis:

Hypothesis 4. Higher levels of cultural fit between partners will be associated with higher levels of alliance performance.

\section{Organizational fit}

Organizational fit is the extent of similarity in the partners' organizational capabilities, such as processes and organizational design (Sarkar et al., 2001; Swoboda et al., 2011). Compatibility in organizational capabilities between alliance partners affects the potential for the formation of synergy between partners (Madhok \& Tallman, 1998). Cartwright and Cooper (1993) suggest that organizational fit is as important as cultural fit in the analysis and evaluation of potential alliance partners. According to Sarkar et al. (2001), the primary indications of organizational fit are compatible technical capabilities between partners, compatible organizational procedures, similar professional skills of employees, and complementary assets of partners. Further, Sampson (2007) suggests that similarity in partner resources can improve alliance outcomes. As greater similarity in organizational procedures, organizational properties, and knowledge bases enhances alliance success, we propose the following hypothesis:

Hypothesis 5. Higher levels of organizational fit between partners will be associated with higher levels of alliance performance.

\section{Trust in strategic alliances}

Trust can be defined as the expectation that an individual or group will fulfill obligations, behave in a predictable manner, and negotiate fairly even when the possibility for opportunism is present (Bromiley \& Cummings, 1995). According to Mayer, Davis and Schoorman (1995), interorganizational trust results from the ability, benevolence, and integrity of the trustee as well as the trustor's propensity to trust. Zucker (1986) argues that trust is socially produced through three main modes: (1) the experience of past exchanges or the expectations and objectives attached to a future exchange, (2) the sharing of common characteristics, such as culture, and (3) formal institutional mechanisms that provide guarantees that transactions will occur as promised. Based on the arguments above, the formation of trust can be considered to rely on relationship-specific factors, as the first mode of trust formation applies to the concept of strategic fit, the second mode, to cultural fit, and the third mode, to organizational fit. When two firms have congruent strategies in an alliance, share the same values concerning the alliance, and have compatible organizational systems and procedures, developing mutual understanding and predicting each other's behavior will be easier for them. Therefore, overall partner fit will lead to higher levels of partner trustworthiness in alliances. We thus propose the following hypotheses concerning the impact of relationship-specific factors (i.e., strategic fit, cultural fit, and organizational fit):

Hypothesis 6. Higher levels of strategic fit between partners will be associated with higher levels of perceived partner trustworthiness.

Hypothesis 7. Higher levels of cultural fit between partners will be associated with higher levels of perceived partner trustworthiness.

Hypothesis 8. Higher levels of organizational fit between partners will be associated with higher levels of perceived partner trustworthiness.

Trust motivates partners to work hard to achieve solutions to difficult conflicts and misunderstandings. Trust leads to effective coordination and thus successful alliances. Therefore, we hypothesize that partner trustworthiness mediates the relationship between relationship-specific factors (i.e., strategic fit, cultural fit, and organizational fit) and alliance performance.

Hypothesis 9a. Perceived partner trustworthiness will mediate the relationship between strategic fit and alliance performance.

Hypothesis 9b. Perceived partner trustworthiness will mediate the relationship between cultural fit and alliance performance.

Hypothesis 9c. Perceived partner trustworthiness will mediate the relationship between organizational fit and alliance performance.

\section{Strategic alliance performance}

Assessing the performance of strategic alliances is notoriously difficult (Contractor, 2005; Olk, 2002). Alliances 
are unique in that they are the only form of economic organization in which firms must maintain a relationship while concentrating on performance issues (Rahman, 2007). Therefore, the relational issues of alliances, such as trust, and the goal-accomplishing or task-oriented aspects of alliances, such as financial performance, operational performance, and organizational effectiveness, are both considered in the evaluation of alliance performance.

\section{Research model}

Figure 1 provides the research model, which illustrates the relationship between alliance performance and its antecedents (firm-specific factors, i.e., alliance orientation of the focal firm, partner selection criteria applied by the focal firm; and relationship-specific factors, i.e., strategic fit, cultural fit and organizational fit between partners) of alliance performance; the relationship between relationship-specific factors and partner trustworthiness; and the mediating role of partner trustworthiness between relationship-specific factors and alliance performance.

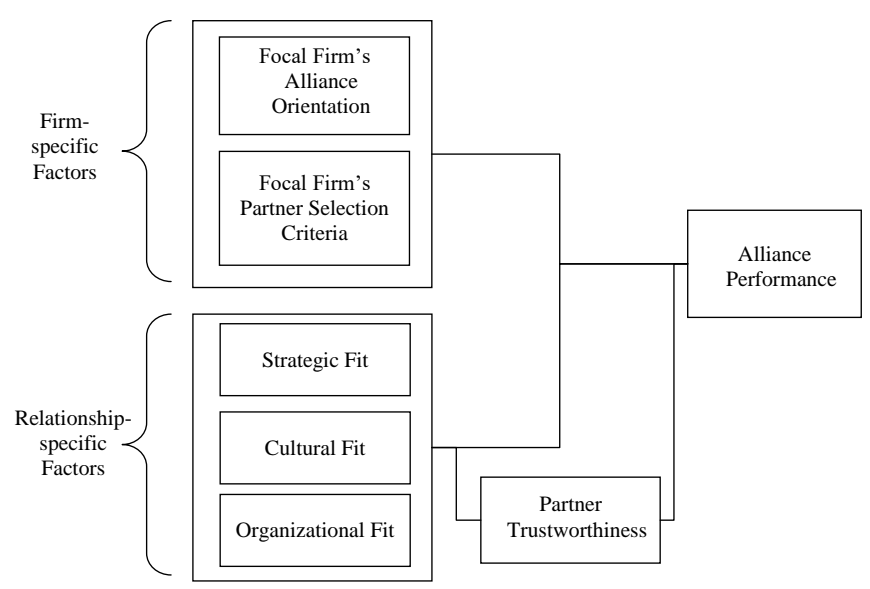

Figure 1: Research model

\section{Method}

\section{Sample and data collection}

A two-stage sample design was used in this study. In the first stage, a probability sample design was applied. A systematic sample method was utilized to randomly select a total of 360 companies out of 713 firms either listed in the Istanbul Chamber of Industry's top 500 companies (ISO500) or quoted on the Istanbul Stock Exchange (ISE). A web link for the questionnaire was then sent to contact people (managers who had direct information about strategic alliances in which their firms were engaged) for those 360 selected companies through electronic mail. The managers were asked to choose a strategically important alliance in which they have been involved. In the second stage, a snowball sample design was applied. In total, we collected 139 questionnaires, 106 of which were found to be valid.

\section{Measures}

All study measures use five-point Likert scales with anchors strongly disagree $(=1)$ and strongly agree $(=5)$. Measurement items and results of reliability analyses are provided in Appendix A. Items measuring alliance orientation (nine items) are adopted from the scale developed by Kandemir et al. (2006). Items measuring the level of partner selection criteria applied (six items) are derived from several resources (i.e. Child et al., 2005; Li \& Rowley, 2002; Sarkar et al., 2001). Items measuring strategic fit (three items) are selected from a four-item scale developed by Taylor (2005). Cultural fit (three items) and organizational fit (four items) items are adopted from Sarkar et al. (2001). As to partner's trustworthiness, six items are used, two of which are adopted from Mayer and Davis (1999). Finally, items measuring alliance performance are selected from scales used in Aulakh and Madhok (2002) and Zollo, Reuer and Singh (2002). The questionnaire also consisted of questions about the characteristics of the alliance such as motives for forming the alliance, alliance type and alliance relationship length.

\section{Results}

\section{Sample characteristics}

The sample distribution for alliance type is presented in Table 1. Equity alliances (i.e., joint ventures) compose $21.7 \%$ of the total sample, whereas non-equity alliances (i.e., contractual agreements) form $78.3 \%$.

Table 1: Alliance type distribution of the sample

\begin{tabular}{|c|c|c|c|c|}
\hline & Alliance Type & Frequency & $\mathrm{Pe}$ & cent \\
\hline $\begin{array}{l}\text { Equity } \\
\text { Alliances }\end{array}$ & Joint Venture & 23 & 21.7 & 21.7 \\
\hline \multirow{5}{*}{$\begin{array}{l}\text { Non- } \\
\text { equity } \\
\text { alliances }\end{array}$} & $\begin{array}{l}\text { Licensing, Franchising, } \\
\text { Dealership }\end{array}$ & 24 & 22.6 & \multirow{4}{*}{78.3} \\
\hline & Outsourcing & 30 & 28.3 & \\
\hline & $\begin{array}{l}\text { Joint Project Dev. - } \\
\text { Joint R\&D }\end{array}$ & 16 & 15.1 & \\
\hline & $\begin{array}{l}\text { Joint Process } \\
\text { (Marketing, } \\
\text { Purchasing, } \\
\text { Production) }\end{array}$ & 13 & 12.3 & \\
\hline & Total & 106 & 100 & 100 \\
\hline
\end{tabular}

The distribution of relationship length for each type of alliance in the sample is presented in Table 2. Joint ventures have a relatively longer relationship length compared with other types of strategic alliances $(65.2 \%$ of the joint ventures in the sample have a relationship length of 4 years or longer). By contrast, "Joint Project Development - Joint Research and Development" alliances have a relatively shorter relationship length, as $81.3 \%$ of these alliances have a relationship length of 3 years or shorter. In the overall sample, $48.1 \%$ of the alliances have a relationship length of 3 years or shorter, $40.6 \%$ of the alliances have a relationship length between 4 and 15 years, and the remaining $11.3 \%$ have a relationship length of 16 years and more. 
Table 2: Alliance type and relationship length distribution of the sample

\begin{tabular}{|c|c|c|c|c|c|}
\hline \multirow[b]{2}{*}{ Alliance Type } & & \multicolumn{3}{|c|}{ Relationship Length } & \multirow{3}{*}{\begin{tabular}{|r|} 
Total \\
\\
23 \\
100.0 \\
21.7
\end{tabular}} \\
\hline & & \multirow{2}{*}{$\begin{array}{c}\mathbf{0 - 3} \text { years } \\
8 \\
34.8 \\
7.5\end{array}$} & \multirow{2}{*}{$\begin{array}{c}\text { 4-15 years } \\
11 \\
47.8 \\
10.4\end{array}$} & \multirow{2}{*}{$\begin{array}{c}16 \text { years and } \\
\text { above }\end{array}$} & \\
\hline Joint Venture & $\begin{array}{c}\text { Count } \\
\% \text { within Alliance Type } \\
\% \text { of Total }\end{array}$ & & & & \\
\hline Licensing, Franchising, Dealership & $\begin{array}{c}\text { Count } \\
\% \text { within Alliance Type } \\
\% \text { of Total } \\
\end{array}$ & $\begin{array}{r}9 \\
37.5 \\
8.5 \\
\end{array}$ & $\begin{array}{r}10 \\
41.7 \\
9.4 \\
\end{array}$ & $\begin{array}{r}5 \\
20.8 \\
4.7 \\
\end{array}$ & $\begin{array}{r}24 \\
100.0 \\
22.6 \\
\end{array}$ \\
\hline Outsourcing & $\begin{array}{c}\text { Count } \\
\% \text { within Alliance Type } \\
\% \text { of Total } \\
\end{array}$ & $\begin{array}{c}12 \\
40.0 \\
11.3 \\
\end{array}$ & $\begin{array}{c}17 \\
56.7 \\
16.0 \\
\end{array}$ & $\begin{array}{c}1 \\
3.3 \\
0.9 \\
\end{array}$ & $\begin{array}{r}30 \\
100.0 \\
28.3 \\
\end{array}$ \\
\hline Joint Project Dev. - Joint R\&D & $\begin{array}{c}\text { Count } \\
\% \text { within Alliance Type } \\
\% \text { of Total }\end{array}$ & $\begin{array}{c}13 \\
81.3 \\
12.3 \\
\end{array}$ & $\begin{array}{r}3 \\
18.8 \\
2.8 \\
\end{array}$ & $\begin{array}{c}0 \\
0.0 \\
0.0 \\
\end{array}$ & $\begin{array}{r}16 \\
100.0 \\
15.1 \\
\end{array}$ \\
\hline Joint Process & $\begin{array}{c}\text { Count } \\
\% \text { within Alliance Type } \\
\% \text { of Total }\end{array}$ & $\begin{array}{r}9 \\
69.2 \\
8.5 \\
\end{array}$ & $\begin{array}{r}2 \\
15.4 \\
1.9 \\
\end{array}$ & $\begin{array}{r}2 \\
15.4 \\
1.9 \\
\end{array}$ & $\begin{array}{r}13 \\
100.0 \\
12.3 \\
\end{array}$ \\
\hline Total & $\begin{array}{c}\text { Count } \\
\% \text { within Alliance Type } \\
\% \text { of Total }\end{array}$ & $\begin{array}{c}51 \\
48.1 \\
48.1 \\
\end{array}$ & $\begin{array}{c}43 \\
40.6 \\
40.6 \\
\end{array}$ & $\begin{array}{c}12 \\
11.3 \\
11.3 \\
\end{array}$ & $\begin{array}{c}106 \\
100.0 \\
100.0 \\
\end{array}$ \\
\hline
\end{tabular}

\section{Test of hypotheses}

The research model was estimated by using the partial least squares (PLS) method, which has been developed as an alternative causal method approach to address small data samples (Wold, 1974). PLS analysis is used for this research model for several reasons. First, under conditions of measurement error, traditional statistical techniques such as multiple regression may fail to accurately estimate interactions (McClelland \& Judd, 1993). The estimation in PLS is based on ordinary least squares (OLS) fixed-point iterations on subsets of model parameters (Fornell \& Larcker, 1981); thus, few distributional assumptions are required. The PLS analysis was conducted using the PROC PLS procedure of SAS 9.1 for Windows. The PLS procedure in SAS/STAT software fits models using any one of a number of linear predictive methods, including partial least squares (PLS). A PLS model is analyzed in two stages: (a) the assessment of reliability and validity of the measurement model, and (b) the testing of the structural model (Hulland, 1999). The adequacy of the measurement model was assessed in previous sections through reliability analysis of scales and factor analyses. In this section, the adequacy of scales will be further analyzed through examining convergent and discriminant validity. Fornell and Larcker (1981) suggest the use of average variance extracted to assess convergent and discriminant validity. Convergent validity of a construct is measured by the ratio of the amount of variance of its indicators captured by the construct, relative to the total amount of variance, including the variance due to measurement error; this ratio is called "average variance extracted (AVE)". As a general rule, a ratio of less than 0.50 is judged inappropriate as more variance is due to error. Satisfactory discriminant validity among constructs is obtained when the squared correlation between any two constructs is statistically less than AVE. This implies that the variance shared between any two constructs is less than the variance shared between a construct and its indicators (Fornell \& Larcker, 1981).

The descriptive statistics, bivariate correlations (shared variances), and average variance extracted values are presented in Table 3. The average variance extracted for each construct ranged between 0.56 and 0.84 , where values greater than 0.50 are adequate for convergent validity. The shared variances (off diagonal elements) were mostly found to be lower than the average variances extracted for the individual constructs (diagonal elements); therefore, the conditions for discriminant validity were partially met. To statistically evaluate the model, the resampling procedure called jackknifing was applied (Fenwick, 1979). A total of 106 jackknife samples were formed, and PLS analysis was applied to all of the jackknife samples. The jackknife estimate is calculated as the mean value of the results of the PLS analyses for 106 jackknife samples. 
Table 3: Descriptive statistics, construct correlations and average variances extracted for the study variables

\begin{tabular}{|c|c|c|c|c|c|c|c|c|c|}
\hline & Mean & SD & 1 & 2 & 3 & 4 & 5 & 6 & 7 \\
\hline (1) Alliance Orientation & 3.81 & 0.67 & $0.84^{\mathrm{a}}$ & & & & & & \\
\hline (2) Partner Selection Criteria & 4.00 & 0.69 & 0.75 & $0.74^{\mathrm{a}}$ & & & & & \\
\hline (3) Strategic Fit & 3.88 & 0.72 & 0.43 & 0.36 & $0.56^{\mathrm{a}}$ & & & & \\
\hline (4) Cultural Fit & 3.56 & 0.73 & 0.46 & 0.45 & 0.72 & $0.56^{\mathrm{a}}$ & & & \\
\hline (5) Organizational Fit & 3.49 & 0.76 & 0.34 & 0.40 & 0.62 & 0.67 & $0.69^{\mathrm{a}}$ & & \\
\hline (6) Partner Trustworthiness & 3.86 & 0.57 & 0.33 & 0.37 & 0.51 & 0.59 & 0.46 & $0.56^{\mathrm{a}}$ & \\
\hline (7) Alliance Performance & 3.70 & 0.63 & 0.49 & 0.28 & 0.64 & 0.59 & 0.57 & 0.44 & $0.78^{\mathrm{a}}$ \\
\hline
\end{tabular}

All correlations are significant at the 0.01 level (2-tailed).

a: Average Variance Extracted

Table 4 includes the hypothesized variables and the control variable (i.e., alliance type). To assess the significance of the PLS results, the t statistic was calculated (Fenwick, 1979). The results showed that the $\mathrm{R}$ square for Model 1 was 0.556 . Alliance orientation was statistically significant at the 0.01 level $(\beta=0.48)$, providing support for a positive main effect of alliance orientation on alliance performance (Hypothesis 1). Strategic fit was statistically significant at the 0.05 level $(\beta=0.28)$, supporting the hypothesized positive relationship between strategic fit and alliance performance (Hypothesis 3 ). Further, the coefficient for the partner selection criteria variable was negative and significant at the 0.05 level, indicating a negative effect of partner selection criteria on alliance performance and opposing Hypothesis 2. Cultural fit, organizational fit, and the control variable (i.e., alliance type) did not have any significant effects on alliance performance, providing no support for Hypotheses 4 and 5. Next, the mediating variable, partner trustworthiness, was included in the model in addition to the main effects (and the control variable). The results are presented in the columns of Table 4 for Model 2. Using the procedures suggested by Tabachnick and Fidell (2007), we found that the increase in the R square attributable to the mediating effect was not statistically significant $\left(F_{1,98}=1.30<F_{\text {critical }}=3.92\right)$. There was no significant effect of partner trustworthiness on alliance performance; thus, we found no support for Hypotheses 9a9c.

\section{Table 4: PLS analysis results}

\begin{tabular}{|c|c|c|c|c|c|c|c|c|c|c|}
\hline \multirow[b]{2}{*}{ Independent Variables } & \multicolumn{5}{|c|}{ Model 1} & \multicolumn{5}{|c|}{ Model 2} \\
\hline & $\begin{array}{c}\text { PLS } \\
\text { Estimate }\end{array}$ & $\begin{array}{l}\text { Jacknife } \\
\text { Estimate }\end{array}$ & $\begin{array}{l}\text { Std. } \\
\text { Dev. }\end{array}$ & t-value & p-value & $\begin{array}{c}\text { PLS } \\
\text { Estimate }\end{array}$ & $\begin{array}{l}\text { Jacknife } \\
\text { Estimate }\end{array}$ & $\begin{array}{l}\text { Std. } \\
\text { Dev. }\end{array}$ & t-value & p-value \\
\hline Alliance orientation & $0.48 * *$ & 0.49 & 0.01 & 3.35 & 0.00 & $0.49 *$ & 0.49 & 0.01 & 2.18 & 0.03 \\
\hline Partner selection criteria & $-0.35 *$ & -0.36 & 0.01 & -1.99 & 0.05 & $-0.37 *$ & -0.37 & 0.01 & -2.43 & 0.02 \\
\hline Strategic Fit & $0.28 *$ & 0.28 & 0.01 & -2.88 & 0.00 & $0.27 * *$ & 0.26 & 0.01 & -5.38 & 0.00 \\
\hline Culture Fit & 0.13 & 0.13 & 0.01 & -0.11 & 0.91 & 0.09 & 0.09 & 0.01 & 1.92 & 0.06 \\
\hline Organizational Fit & 0.28 & 0.28 & 0.01 & -0.58 & 0.57 & 0.28 & 0.28 & 0.01 & 1.88 & 0.06 \\
\hline Control Variable (Alliance Type) & 0.06 & 0.06 & 0.01 & 0.67 & 0.51 & 0.05 & 0.06 & 0.01 & 1.62 & 0.11 \\
\hline Partner Trustworthiness & & & & & & 0.10 & 0.10 & 0.01 & 1.11 & 0.27 \\
\hline $\begin{array}{l}\text { R2 } \\
\text { delta R2 }\end{array}$ & 0.56 & & & & & $\begin{array}{l}0.56 \\
0.01\end{array}$ & F-value: & 1.30 & & 0.26 \\
\hline
\end{tabular}

Endogenous variable: alliance performance

$* \mathrm{p}<.05$

$* * \mathrm{p}<.01$

\section{Discussion and implications}

This study explores and analyzes the dynamics of strategic alliances by evaluating data from 106 strategic alliances in Turkey. Several hypotheses were tested with PLS analysis by using the data from the survey.

Alliance Orientation. Hypothesis 1, proposing that higher levels of alliance orientation would be associated with higher levels of alliance performance, was supported. Alliance orientation refers to the extent to which a firm scans its environment for alliance opportunities, coordinates its activities across its different alliances, and learns from the alliance experience it gains (Kandemir et al., 2006).

Partner Selection Criteria. An interesting, statistically significant finding from the study was that, contrary to Hypothesis 2, the number of partner selection criteria applied by a firm is negatively related to alliance performance. The selection of an appropriate partner is considered a critical issue for the success of strategic alliances, as alliance success is determined largely by appropriate partner selection (Child et al., 2005; Hitt, Tyler, Hardee \& Park, 1995; Shah \& Swaminathan, 2008). The partner selection process adopted by firms usually covers every perspective to evaluate partner alternatives. However, the study findings indicate that exerting greater effort in selecting the appropriate partner will lead to lower alliance performance. Several reasons may explain this outcome. First, if a firm applies too many criteria when selecting its partners, a potential partner that succeeds in this selection process and that is selected as the appropriate partner will be perceived as "the ideal partner". The heightened expectations for this ideal partner may increase the potential for disappointment. Even if the partner operates with a moderate level of success, the perceived alliance 
performance might be low because the best is expected from that firm. Another explanation for this finding may be the lack of contextual factors in the research model. Shah and Swaminathan (2008) argue that partner selection criteria will vary based on the context in which an alliance operates. In an uncertain environment, finding the right partner is not as critical because the circumstances will probably change after the partner is selected and after the cooperative relationship is formed. Therefore, the concept of "the ideal partner" would be vague and contingent on the continuous change in the environment.

Strategic Fit. Hypothesis 3, proposing that higher levels of strategic fit between alliance partners would be associated with higher levels of alliance performance, was supported in the data analysis. Strategic fit can be defined as the extent to which partners have congruent firm-level strategies, as well as compatible strategies for the alliance itself, and the strengths and capabilities of the partners form a synergy within the alliance (Lunnan \& Haughland, 2008; Taylor, 2005). One of the primary reasons for engaging in cooperative agreements is to create synergy with the partner (Sarkar et al., 2001; Child et al., 2005) and to gain access to capabilities that the focal firm lacks. Therefore, establishing a strategic fit between partners will lead to a successful alliance.

Cultural Fit. Hypothesis 4, proposing that higher levels of cultural fit between partners would be associated with higher levels of alliance performance, did not find support. However, Hypothesis 7, indicating that higher levels of cultural fit would be associated with higher levels of partner trustworthiness, did find support. In the alliance literature, wide range of research suggests that congruent organizational cultures increase the level of mutual trust among alliance partners. Further, shared values and mutual understanding make it easier for alliance partners to enhance mutual trust.

Organizational Fit. Hypothesis 5, proposing that higher levels of organizational fit between partners would be associated with higher levels of alliance performance, was not supported. Organizational fit refers to the extent of congruence in the partners' procedural capabilities. Congruence in technical capabilities and organizational procedures develops over time, as the professional skills of employees become similar and as partners start sharing compatible assets (Ahuja, 2000; Lane \& Lubatkin, 1998; Luo, 2008; Sampson, 2007; Sarkar et al., 2001). As the alliance becomes increasingly mature, the organizational systems of the alliance partners can more effectively manage the alliance. Therefore, relationship length is critical for developing an organizational fit between alliance partners.

Partner Trustworthiness. Hypotheses 9a-9c, proposing that partner trustworthiness mediates the relationship between relationship-specific factors (i.e., strategic fit, cultural fit, and organizational fit) and alliance performance, were not supported. Although a significant amount of alliance research indicates that a relationship exists between trust and performance (Gambetta, 1988; Krishnan, Martin \& Noorderhaven, 2006; Mayer et al., 1995; McEvily, Perrone
\& Zaheer, 2003), in this study, partner trustworthiness did not have a significant relationship with alliance performance. Shah and Swaminathan (2008) argue that trust is more important when more tangible measures of outcomes are absent. When the outcomes of an alliance are difficult to interpret, trust between partners will be the primary basis for the evaluation of alliance outcomes. Thus, trust and performance might be evaluated as two separate perspectives on alliance outcomes. Additionally, according to McEvily et al. (2003), trust does not always improve alliance performance. Indeed, research on interorganizational trust has covered contingency factors that affect the relationship between trust and alliance performance (Carson, Madhok, Varman \& John, 2003; Krishnan et al., 2006; Langfred, 2004). These studies suggest that the benefits of trust may be larger in certain contexts and smaller in others.

The findings of this study showed that alliance orientation helps firms to achieve alliance success. Therefore, firms should concentrate on developing their capabilities with respect to alliance orientation. Firms should include a dedicated organizational unit for alliance orientation, and this unit can act as a center for scanning alliance opportunities, coordinating alliance activities, and learning lessons from prior and current alliances. The fit between alliance partners is also critical for alliance success. Pooling complementary skills and assets leads to superior alliance outcomes, and similarities can help partners perform more effectively. Therefore, the existence of strategic, cultural, and organizational fit is of great importance in alliance management. Additionally, the results of this study showed that cultural fit is positively related to partner trustworthiness; therefore, cultural fit should be ensured in an alliance to foster the development of mutual trust. Culture is not easily observed. As the relationship develops, a mutual understanding of shared values begins to appear. Similar philosophies between executives, congruent organizational values and norms, and the right chemistry between partners lead to higher levels of trust between partners. An alliance that develops fit between the partners in every dimension and that facilitates trust will have a higher likelihood of sustained success.

\section{Conclusion}

This study evaluated the dynamics of strategic alliances by investigating the impact of firm-specific (i.e., alliance orientation and partner selection criteria) and relationshipspecific (i.e., strategic fit, cultural fit, and organizational fit) factors on alliance performance and by assessing the mediating role of partner trustworthiness in the relationship between relationship-specific factors and alliance performance. The results of this research contribute to the literature in several important ways. By developing and testing the research model, the study adds theoretical and managerial contributions to the growing strategic alliance research stream. First, in previous alliance studies, firm- and relationship-specific characteristics have rarely been analyzed together in a single model. This study aimed to address this research gap by bringing these two types of factors together in a unified conceptual framework. Second, 
the results indicate that the alliance capability developed by firms (i.e., alliance orientation) has a significant positive effect on alliance performance. Thus, the study emphasizes that firms that spend time, effort, and resources developing their capability for alliance management will outperform their competitors. Third, this study also contributes a greater understanding of the importance of partner fit for firms in forming and sustaining successful alliances. The results indicated that strategic fit leads to superior alliance performance and that cultural fit is positively related to partner trustworthiness. The findings from this research thus provide some guidelines for firms in achieving superior alliance performance. We hope that the theoretical foundations and managerial implications of this study will contribute to enhancing the understanding of strategic alliances and stimulate further investigations on the topic.

\section{References}

Aiuniddin, R.A., Beamish, P.W., Hulland, J.S. \& Rouse, M.J. 2007. 'Resource attributes and firm performance in international joint ventures', Journal of World Business, 42: 47-60.

Ahuja, G. 2000. 'Collaboration networks, structural holes and innovation: A longitudinal study', Administrative Science Quarterly, 45: 425-457.

Anderson, J.C. \& Narus, J.A. 1990. 'A model of distributor firm and manufacturing firm working partnerships', Journal of Marketing, 54(1): $42-58$.

Argyris, C. \& Schön, D.A. 1978. Organizational learning: A theory of action perspective. Reading, MA: Addison-Wesley.

Aulakh, P.S. \& Madhok, A. 2002. Cooperation and performance in international alliances: The critical role of flexibility. In Contractor, F.J. \& Lorange, P. (Eds.). Cooperative strategies and alliances. Oxford: Elsevier Science.

Auster, E.R. 1990. The interorganizational environment: Network theory, tools, and applications. In Williams, F. \& Gibson, D. (Eds.). Technology transfer: A communication perspective. Newbury Park, CA: Sage Publications.

Barney, J. 1991. 'Firm resources and sustained competitive advantage', Journal of Management Studies, 17(1): 99-120.

Beamish, P.W. \& Delios, A. 1997. Incidence and propensity of alliance formation in U.S., Japanese and European MNEs. In Beamish, P.W. \& Killing, J.P. (Eds.). Cooperative strategies: Asian pacific perspectives. San Francisco: New Lexington Press.

Bromiley, P. \& Cummings, L.L. 1995. Transaction costs in organizations with trust. In Bies, R., Sheppard, B. \& Lewicki, R. (Eds.). Research on negotiation in organizations. Greenwich, CT: JAI Press.

Carlson, B.D., Franwick, G.L. \& Cuminskey, K.J. 2011. 'A framework for understanding new product alliance success', Journal of Marketing Theory and Practice, 19(1): 7-25.

Carson, S.J., Madhok, A., Varman, R. \& John, G. 2003. 'Information processing moderators of the effectiveness of trustbased governance in inter-firm R\&D collaboration', Organization Science, 14: 45-56.
Cartwright, S. \& Cooper, C.L. 1993. 'The role of culture compatibility in successful organization', The Academy of Management Executive, 7(2): 57-69.

Chand, M. \& Katou, A.A. 2011. 'Strategic determinants for the selection of partner alliances in the Indian tour operator industry: A cross-national study', Journal of World Business, 47(2): 167-177.

Child, J., Faulkner, D. \& Tallman, S. 2005. Cooperative strategy: Managing alliances, networks and joint ventures. New York: Oxford University Press.

Contractor, F.J. 2005. 'Alliance structure and process: Will the two research streams ever meet in alliance research?', European Management Review, 2: 123-129.

Das, T.K. \& Teng, B. 1998a. 'Between trust and control: Developing confidence in partner cooperation in alliances', Academy of Management Review, 23: 491-512.

Das, T.K. \& Teng, B. 1998b. 'Resource and risk management in the strategic alliance making process', Journal of Management, 24: 21 42.

Digman, L. A. 1999. Strategic management: Concepts, processes, decisions. Houston, Texas, U.S.A.: Dame Publications.

Eisenhardt, K. \& Schoonhoven, C.B. 1996. 'Resource-based view of strategic alliance formation: Strategic and social effects in entrepreneurial firms', Organization Science, 7: 136-150.

Fenwick, I. 1979. 'Techniques in market measurement: The jackknife', Journal of Marketing Research, 16: 410-414.

Fornell, C. \& Larcker, D.F. 1981. 'Evaluating structural equation models with unobservable variables and measurement error', Journal of Marketing Research, 18: 39-50.

Gambetta, D. G. 1988. Can we trust trust? In Gambetta, D. G. (Ed.). Trust. New York: Basil Blackwell.

Hagedoorn, J. 1993. 'Understanding the rationale of strategic technology partnering: Inter-organizational modes of cooperation and sectoral differences', Strategic Management Journal, 14: 371385 .

Hitt, M.A., Tyler, B.B., Hardee, C. \& Park, D. 1995. 'Understanding strategic intent in the global marketplace', Academy of Management Executive, 9: 12-19.

Hitt, M.A., Dacin, T.M., Levitas, E., Arregle, J. \& Borza, A. 2000. 'Partner selection in emerging and developed market contexts: Resource-based and organizational learning perspectives', Academy of Management Journal, 43(3): 449-467.

Hoffman, W. \& Schlosser, R. 2001. 'Success factors of strategic alliances in small and medium sized enterprises - an empirical survey', Long Range Planning, 34: 357-381.

Hulland, J. 1999. 'Use of partial least squares (PLS) in strategic management research: A review of four recent studies', Strategic Management Journal, 20(2): 195-204.

Inkpen, A.C. 1997. An examination of knowledge management in international joint ventures. In Beamish, P.W. \& Killing, J.P. (Eds.). Cooperative strategies: North American perspective. San Francisco, CA: New Lexington Press. 
Jiang, X. \& Li, Y. 2008. 'The relationship between organizational learning and firms' financial performance in strategic alliances: A contingency approach', Journal of World Business, 43: 365-379.

Kale, P. \& Singh, H. 2007. 'Building firm capabilities through learning: The role of the alliance learning process in alliance capability and firm-level alliance success', Strategic Management Journal, 28: 981-1000.

Kandemir, D., Ghauri, P. \& Cavusgil, S.T. 2002. The strategic role of organizational learning in relationship quality in strategic alliances. In Contractor, F.J. \& Lorange, P. (Eds.). Cooperative strategies and alliances. Oxford: Elsevier Science.

Kandemir, D., Yaprak, A. \& Cavusgil, S.T. 2006. 'Alliance orientation: Conceptualization, measurement and impact on market performance', Journal of the Academy of Marketing Science, 34(3): 324-340.

Kanter, R.M. 1994. 'Collaborative advantage: The art of alliances', Harvard Business Review, 72(4): 96-108.

Kogut, B. 1988. 'Joint ventures: Theoretical and empirical perspectives', Strategic Management Journal, 9: 319-32.

Kogut, B. \& Zander, U. 1992. 'Knowledge of the firm and evolutionary theory of multinational corporation', Organization Science, 3: 383- 397.

Krishnan, R., Martin, X. \& Noorderhaven, N.G. 2006. 'When does trust matter to alliance performance?', Academy of Management Journal, 49(5): 894-917.

Lane, P.J. \& Lubatkin, M. 1998. 'Relative absorptive capacity and organizational learning', Strategic Management Journal, 19: 461477.

Langfred, C.W. 2004. 'Too much of a good thing? Negative effects of high trust and individual autonomy in self-managing teams', Academy of Management Journal, 47: 385-399.

Li, S. X. \& Rowley, T.J. 2002. 'Inertia and evaluation mechanisms in interorganizational partner selection: Syndicate formation among U.S. investment banks', Academy of Management Journal, 45(6): 1104-1119.

Lin, Z., Yang, H. \& Arya, B. 2009. 'Alliance partners and firm performance: Resource complementarity and status association', Strategic Management Journal, 30: 921-940.

Lunnan, R. \& Haughland, S.A. 2008. 'Predicting and measuring alliance performance: A multidimensional analysis', Strategic Management Journal, 29: 545-556.

Luo, Y. 2008. 'Structuring interorganizational cooperation: The role of economic integration in strategic alliances', Strategic Management Journal, 29: 617-637.

Lynch, R.P. 1993. Business alliance guide: The hidden competitive weapon. New York: John Wiley \& Sons.

Madhok, A. \& Tallman, S.B. 1998. 'Resources, transactions, and rents: Managing value through interfirm collaborative relationships', Organization Science, 9(3): 326-339.
Mayer, R.C. \& Davis, J. 1999. 'The effect of performance appraisal system on trust for management: A field quasi-experiment', Journal of Applied Psychology, 84: 123-36.

Mayer, R.C., Davis, J.H. \& Schoorman, F.D. 1995. 'An integrative model of organizational trust', Academy of Management Review, 20 709-734.

McClelland, G.H. \& Judd, C.M. 1993. 'Statistical difficulties of detecting interactions and moderator effects', Psychological Bulletin, 114(2): 376-390.

McEvily, B., Perrone, V. \& Zaheer, A. 2003. 'Trust as an organizing principle', Organization Science, 14: 91-103.

Meirovich, G. 2010. 'The impact of cultural similarities and differences on performance in strategic partnerships: An integrative perspective', Journal of Management \& Organization, 16: 127-139.

Narver, J.C. \& Slater, S.F. 1990. 'The effect of market orientation on business profitability', Journal of Marketing, 54(4): 20-35.

Nonaka, I. 1991. 'The knowledge-creating company', Harvard Business Review, 69: 96-104.

Olk, P. 2002. Evaluating strategic alliance performance. In Contractor, F.J.\& Lorange, P. (Eds.). Cooperative strategies and alliances. Oxford: Elsevier Science.

Pansiri, J. 2008. 'The effects of characteristics of partners on strategic alliance performance in the SME dominated travel sector', Tourism Management, 29(1): 101-115.

Parkhe, A. 1993. 'Strategic alliances structuring: A game theoretic and transaction cost examination of cooperation', Academy of Management Journal, 36: 794-829.

Porter, M.E. \& Fuller, M.B. 1986. Coalitions and global strategy. In Porter, M.E. (Ed.). Competition in global industries. Boston, MA: Harvard Business School Press.

Rahman, N. 2007. 'Duality of alliance performance', Journal of American Academy of Business, Cambridge, 10(2): 21-28.

Rice, J., Liao, T-S., Martin, N. \& Galvin, P. 2012. 'The role of strategic alliances in complementing firm capabilities', Journal of Management \& Organization, 18(6): 858-869.

Sampson, R.C. 2007. 'R\&D alliances and firm performance: The impact of technological diversity and alliance organization on innovation', Academy of Management Journal, 50(2): 364-386.

Sarkar, M., Cavusgil, S.T. \& Evirgen, C. 1997. The commitmenttrust framework in international collaborative ventures. In Beamish, P. W. \& Killing, J.P. (Eds.). Cooperative strategies: North American perspectives. San Fransisco: The New Lexington Press.

Sarkar, M.B., Echambadi, R., Cavusgil, S.T. \& Aulakh, P.S. 2001. 'The influence of complementarity, compatibility and relationship capital on alliance performance', Journal of the Academy of Marketing Science, 29(4): 358-373.

Shah, R.H. \& Swaminathan, V. 2008. 'Factors influencing partner selection in strategic alliances: The moderating role of alliance context', Strategic Management Journal, 29: 471-494. 
Speakman, R.E. \& Sawhney, K. 1991. Towards a conceptual understanding of the antecedents of strategic alliances. Management Science Institute, Report No: 90/114.

Swoboda, B., Meierer, M., Foscht, T. \& Morschett, D. 2011. 'International SME Alliances: The impact of alliance building and configurational fit on success', Long Range Planning, 44: 271-288.

Tabachnick B.G. \& Fidell, L.S. 2007. Using multivariate statistics. $5^{\text {th }}$ Edition. Boston: Allyn and Bacon.

Taylor, A. 2005. 'An operations perspective on strategic alliance success factors', International Journal of Operations \& Product Management, 25(5/6): 469-490.

Teece, D.J., Pisano, G. \& Shuen, A. 1997. 'Dynamic capabilities and strategic management', Strategic Management Journal, 18(7): 509533.

Yoshino, M.Y. \& Rangan, U.S. 1995. Strategic alliances: An entrepreneurial approach to globalization. Boston, MA: Harvard Business School Press.
Williamson, O.E. 1985. The economic institutions of capitalism: Firms, markets, relational contracting. New York: The Free Press.

Wohlsetter, P., Smith, J. \& Malloy, C.L. 2005. 'Strategic alliances in action: Toward a theory of evolution', Policy Studies Journal, 33(3): 419-442.

Wold, H. 1974. 'Causal flows with latent variables', European Economic Review, 5: 67-86.

Zollo, M., Reuer, J.J. \& Singh, H. 2002. 'Interorganizational routines and performance in strategic alliances', Organization Science, 13(6): 701-713.

Zucker, L.G. 1986. 'Production of trust: Institutional sources of economic structure, 1840-1920', Research in Organizational Behavior, 8: 53-111. 


\section{Appendix A. Measurement scales and analyses}

\begin{tabular}{|c|c|c|c|}
\hline Source & Scale & $\begin{array}{l}\text { Factor } \\
\text { Loading }\end{array}$ & $\begin{array}{l}\text { Cronbach' } \\
\text { s Alpha }\end{array}$ \\
\hline & Alliance Orientation & & $\mathbf{0 , 8 9}$ \\
\hline \multirow{10}{*}{$\begin{array}{l}\text { Kandemir et al. } \\
\text { (2006) }\end{array}$} & 1. We actively monitor our environment to identify partnering opportunities. & 0,83 & \\
\hline & $\begin{array}{l}\text { 2. We routinely gather information about prospective partners from various forums (e.g., trade } \\
\text { shows, industry conventions, databases, publications, internet etc.). }\end{array}$ & 0,67 & \\
\hline & 3. We are alert to market developments that create potential alliance opportunities. & 0,84 & \\
\hline & 4. Our activities across different alliances are well coordinated. & 0,69 & \\
\hline & 5. We systematically coordinate our strategies across different alliances. & 0,65 & \\
\hline & 6. We have processes to systematically transfer knowledge across alliance partners. & 0,75 & \\
\hline & $\begin{array}{l}\text { 7. We conduct periodic reviews of our alliances to understand what we are doing right and } \\
\text { where we are going wrong. }\end{array}$ & 0,72 & \\
\hline & 8. We periodically collect and analyze field experiences from our alliances. & 0,59 & \\
\hline & 9. We modify our alliance related procedures as we learn from experience. & 0,87 & \\
\hline & Parner Selection Criteria & & $\mathbf{0 , 8 2}$ \\
\hline Items generated & 1. We check whether we have compatible strategies with the partner. & 0,67 & \\
\hline from Sarkar et al. & 2. We check whether we have compatible organizational cultures. & 0,93 & \\
\hline (2001); Li \& & 3. We check whether we have compatible organizational structure and systems. & 0,90 & \\
\hline Rowley (2002); & 4. We check whether the partner firm has succeeded in previous alliance experiences. & 0,68 & \\
\hline Child et al. & 5. We check whether the partner is a legitimate firm. & 0,82 & \\
\hline \multirow[t]{2}{*}{$(2005)$} & 6. We check whether the partner is financially strong. & 0,83 & \\
\hline & Strategic Fit & & $\mathbf{0 , 7 2}$ \\
\hline \multirow[t]{4}{*}{ Taylor (2005) } & 1. We have compatible long-term strategies. & 0,73 & \\
\hline & 2. Our strengths and capabilities form a synergy. & 0,87 & \\
\hline & 3. We have compatible objectives within the alliance. & 0,81 & \\
\hline & Cultural Fit & & 0,67 \\
\hline \multirow{4}{*}{$\begin{array}{l}\text { Sarkar et al. } \\
(2001)\end{array}$} & 1. The organizational values and social norms prevalent in the two firms are congruent. & 0,71 & \\
\hline & $\begin{array}{l}\text { 2. Executives from both firms involved in this alliance had compatible } \\
\text { philosophies/approaches to business dealings. }\end{array}$ & 0,86 & \\
\hline & 3. The chemistry is right between the two firms. & 0,75 & \\
\hline & Organizational Fit & & $\mathbf{0 , 8 0}$ \\
\hline \multirow{3}{*}{$\begin{array}{l}\text { Sarkar et al. } \\
\text { (2001) }\end{array}$} & 1. Technical capabilities of the two firms are compatible with each other. & 0,81 & \\
\hline & 2. The organizational procedures of the two firms are compatible. & 0,82 & \\
\hline & 3. Employees of both firms have similar professional skills. & 0,80 & \\
\hline \multirow[t]{2}{*}{ New item } & 4. We have complementary assets. & 0,73 & \\
\hline & Partner's Trustworthiness & & 0,68 \\
\hline Mayer and Davis & 1. We never have to wonder whether the alliance partner will stick to their word. & 0,82 & \\
\hline 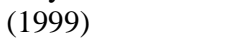 & 2. The alliance partner tries hard to be fair dealing with us. & 0,73 & \\
\hline New item & 3. The partners' top management has good relationships with our management. & 0,78 & \\
\hline New item & 4. The alliance partner is transparent in its activities within the alliance. & 0,57 & \\
\hline New item & 5. The alliance partner behaves opportunistic in some parts of the contract. (RC) & 0,85 & \\
\hline \multirow[t]{2}{*}{ New item } & 6. The alliance partner respects the confidentiality of the contract. & 0,66 & \\
\hline & Alliance Performance & & 0,84 \\
\hline & 1. The partnership with this partner is more profitable than we expected. & 0,78 & \\
\hline \multirow[t]{3}{*}{ Madhok (2002) } & 2. Overall, we consider this partnership to be successful. & 0,77 & \\
\hline & 3. The goals and objectives that we had set at the outset of the partnership have been achieved. & 0,81 & \\
\hline & 4. The partnership with the firm has achieved good market penetration. & 0,79 & \\
\hline $\begin{array}{l}\text { Zollo et al. } \\
(2002)\end{array}$ & 5. We are satisfied with the knowledge accumulated from participating in this alliance. & 0,56 & \\
\hline & 6. The alliance has created new opportunities for our firm. & 0,71 & \\
\hline New item & 7. The return on investment (ROI) of the alliance was satisfactory. & 0,80 & \\
\hline
\end{tabular}

